\title{
A New Approach to Tense End-to-End Anostomosis in Primary Surgical Repair of Esophageal Atresia: Vascularized Pleural Flap
}

\author{
Metin Simsek, Mehmet Mert* \\ Department of Pediatric Surgery, Health Sciences University Van Education and Research Hospital, Van, Turkey
}

*Corresponding author: Mehmet Mert MD

Suphan district, Airport junction

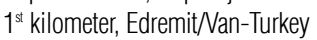

E-mail: dr.mehmet.mert@outlook.com

\section{Rezumat \\ O nouă abordare a anastomozei termino-terminale tensionate în remedierea chirurgicală primară a atreziei esofagiene: lamboul pleural vascularizat}

Introducere: Atrezia esofagiană (AE) este cea mai comună malformație congenitală a esofagului. Dacă distanța între capetele oarbe proximal şi distal este, de regulă, peste $2-3 \mathrm{~cm}$, atrezia se consideră de tip III A. Obiectivul studiului nostru este investigarea utilizării unui lambou pleural vascularizat (LPV) în recuperarea postoperatorie a cazurilor de anastomoză termino-terminală tensionată pentru remedierea primară a atreziei de tip III A.

Metode: $\mathrm{Au}$ fost analizate retrospectiv perioadele de recuperare postoperatorie a pacientilor care au fost supuşi unei anastomoze termino-terminale tensionate pentru atrezie de tip III A între 01.01.2016 şi 12.01.2020 în clinica noastră.

Rezultate: Între datele specificate, au fost operați pentru atrezie esofagiană 37 de pacienți. S-au efectuat anastomoze tensionate termino-terminale la 16 din cei 37 de pacienți. La 5 dintre aceştia s-a plasat un LPV pe linia anastomozei. Nu s-a observat, în cadrul urmăririi postoperatorii, niciun caz de fistulă sau stenoză anastomotică la cei 5 pacienți cu anastomoză tensionată cu LPV. În plus, s-a observat că la pacienții cu anastomoză tensionată cu LPV, alimentarea pe cale orală a putut fi inițiată mai devreme decât la pacientii fără LPV.

Concluzie: Succesul tehnicii efectuate la 5 pacienți fără nicio complicație sugerează că această tehnică poate fi utilizată ca metodă de anastomoză tensionată. S-a considerat că alimentarea pe cale orală a fost inițiată mai devreme la pacienții cu LPV deoarece nu au prezentat fistulă anastomotică, iar chirurgul s-a putut baza pe prezența LPV. 
Cuvinte cheie: atrezie esofagiană, lambou, atrezie esofagiană de tip III

\begin{abstract}
Background: Esophageal atresia (EA) is the most common congenital malformation of the esophagus. If the distance between the proximal and distal pouches is usually more than $2-3 \mathrm{~cm}$, it is considered as long gap esophageal atresia (LGEA). In our study, it was planned to investigate the effect of the use of vascularized pleural flap (VPF) on postoperative recovery in cases with tense end-to-end anastomosis in the primary repair of LGEA.

Methods: The postoperative recovery period data of patients who underwent tense end-to-end anastomosis due to LGEA between 01/01/2016 and 01/12/2020 in our clinic were analyzed retrospectively.

Results: Between the specified dates, 37 patients were operated for EA. A tense end-to-end anastomosis was performed in 16 of 37 patients. In 5 of these patients, a VPF was placed on the anastomosis line. In the postoperative follow-up, no anastomotic leakage or anastomotic stenosis was observed in 5 patients who underwent tense anastomosis with VPF. In addition, it was observed that patients who underwent tense anastomosis with VPF were started oral nutrition earlier after surgery compared to patients without VPF.

Conclusion: The success of the technique we performed in 5 patients without any complications suggested that this technique could be used as a method in tense anastomoses. It was thought that oral nutrition was initiated early in patients using VPF, since there was no anastomotic leak and the surgeon relied on the presence of the VPF.
\end{abstract}

Key words: esophageal atresia, flap, long gap

\section{Introduction}

Esophageal atresia (EA) is the interruption of the upper third of the esophagus and ends as a blind sac behind the membranous trachea. Although EA is the most common congenital malformation of the esophagus, its incidence is 2.43 in 10.000 births (1). There is still no widely accepted definition for the long gap esophageal atresia (LGEA). However, this expression can be defined as too large distance between the proximal and distal parts of the esophagus to allow a non-tense end to end anastomosis to be made. With some traction of both esophagus parts, it is decided that a nontense anastomosis can be made if the distance between them is not more than $1 \mathrm{~cm}$. Considering the literature, the evaluation of the distance between the proximal and distal parts of the esophagus as a long gap range varies among surgeons. Generally, a distance of more than $3 \mathrm{~cm}$ is defined as long gap (2). Different methods have been described for the surgical treatment of LGEA, but this group constitutes the most technically difficult group among the EA cases. In this article, we aimed to investigate the effect of vascularized pleural flap use on postoperative recovery in patients who underwent tense end-to-end anastomosis in primary repair of LGEA.

\section{Materials and Method}

\section{Study Design}

The data of patients who were operated with the diagnosis of LGEA between 01/01/2016 01/12/2020 in the department of pediatric surgery of Health Sciences University Van Education and Research Hospital were examined. In this patient group, the data of the patients who underwent tense end-to-end 
anastomosis recovery period after surgery were analyzed retrospectively.

\section{Vascularized Pleural Flap Method}

Proximal and distal esophageal pouches were found with the extrapleural method from the $4^{\text {th }}$ intercostal space with right posterolateral thoracotomy. In cases evaluated as LGEA, a tense end-to-end anastomosis was performed. Then, a vascularized flap in the form of a triangle was prepared from the parietal pleura with the free side not shorter than the length of 2 vertebrae. This prepared vascularized pleural flap was sutured with 5/0 absorbable separate sutures covering the anastomosis line over than 180 degrees. After the procedure, the vitality of the flap was checked and the surgery was completed.

\section{Statistical Analysis}

Statistical analysis was performed with IBM SPSS Statistics 25.0 (IBM Corp., Armonk, New York, USA). Relationships between continuous variables were evaluated using Spearman's correlation test. A value of $p<0.05$ was considered statistically significant.

\section{Results}

Between 01/01/2016 and 01/12/2020, 37 patients were operated with the diagnosis of EA in the department of pediatric surgery of Health Sciences University Van Education and Research Hospital. Esophagostomy and gastrostomy were performed in 2 of these patients. Non-tension esophagoesophagostomy was performed on 19 of them. These patients were excluded from the study. A tense end-toend anastomosis was performed in the remaining 16 patients. In 5 of 16 patients a vascularized pleural flap was placed on the anastomosis line. In 11 of 16 patients, only a tense end-to-end anastomosis without vascularized pleural flap was performed (Fig. 1).

Birth weights, Spitz's risk classification, type of EA, vascularized pleural flap usage status, oral feeding time (day) after surgery, presence of anastomotic leakage and/or anastomotic stenosis are explained in Table 1.

Considering the birth weight of the patients and major cardiac anomalies, the patients were categorized according to the Spitz's risk classification. In order to evaluate the anastomosis, the esophageal passage was checked with a water-soluble opaque solution between $5^{\text {th- }} 7^{\text {th }}$ days postoperatively. In

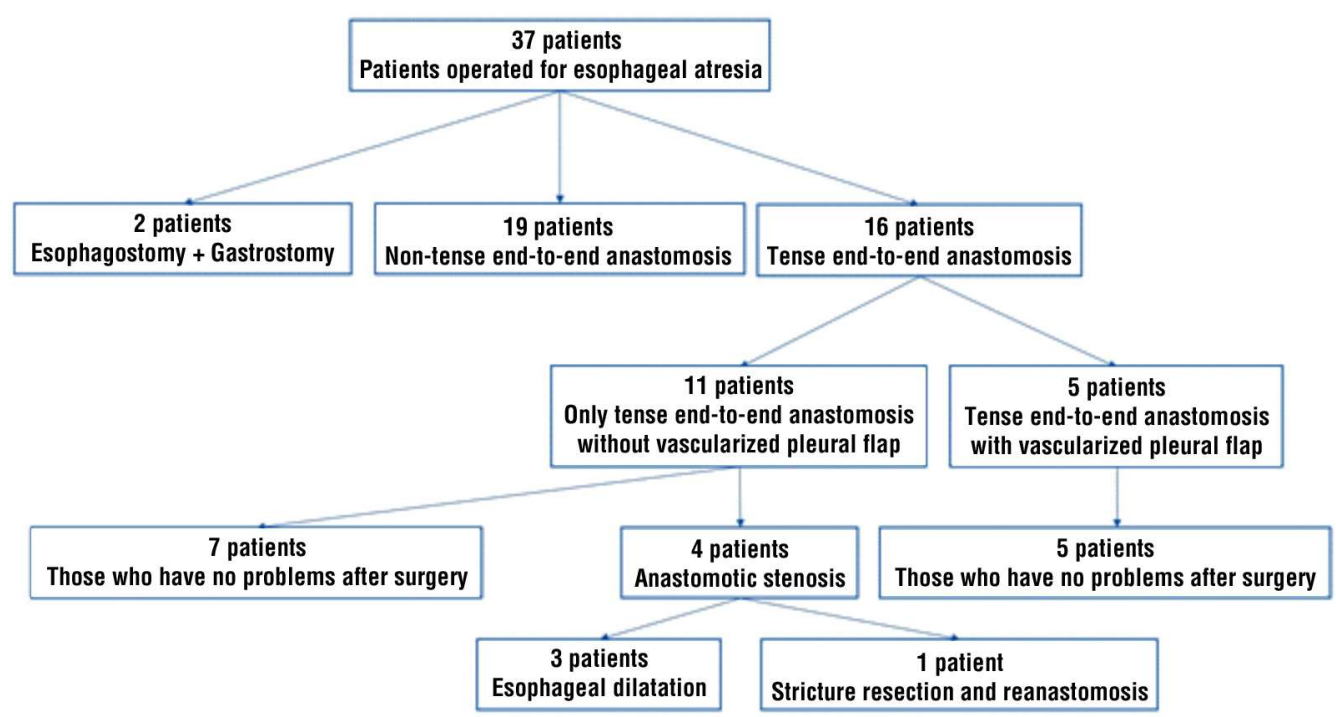

Figure 1. Patients operated with the diagnosis of esophageal atresia 
Table 1. Patients who underwent tense end-to-end anastomosis due to esophageal atresia (EA: Esophageal atresia, *: Anastomotic stricture requiring esophageal dilatation, ${ }^{* *}$ : Anastomotic stricture requiring resection-anastomosis)

\begin{tabular}{|c|c|c|c|c|c|c|c|}
\hline Patient & $\begin{array}{c}\text { Birth } \\
\text { weight }\end{array}$ & $\begin{array}{l}\text { Spitz's risk } \\
\text { classification }\end{array}$ & $\begin{array}{c}\text { Type of EA } \\
\text { (Gross classification) }\end{array}$ & $\begin{array}{c}\text { Vascularized pleural } \\
\text { flap use }\end{array}$ & $\begin{array}{l}\text { Oral feeding time } \\
\text { (day) after surgery }\end{array}$ & $\begin{array}{l}\text { Anastomotic } \\
\text { leakage }\end{array}$ & $\begin{array}{c}\text { Anastomotic } \\
\text { stenosis }\end{array}$ \\
\hline 1 & 1345 & 2 & $A$ & Yes & 7 & No & No \\
\hline 2 & 1600 & 2 & $C$ & Yes & 9 & No & No \\
\hline 3 & 2900 & 2 & C & Yes & 7 & No & No \\
\hline 4 & 2340 & 2 & $A$ & Yes & 6 & No & No \\
\hline 5 & 2460 & 1 & $C$ & Yes & 8 & No & No \\
\hline 6 & 1700 & 1 & $C$ & No & 12 & Yes & Yes* \\
\hline 7 & 2600 & 1 & $B$ & No & 10 & No & No \\
\hline 8 & 2400 & 1 & C & No & 14 & No & Yes* \\
\hline 9 & 3200 & 2 & $C$ & No & 13 & No & No \\
\hline 10 & 1000 & 2 & $C$ & No & 12 & No & No \\
\hline 11 & 2600 & 1 & $C$ & No & 13 & Yes & Yes* \\
\hline 12 & 1000 & 2 & A & No & 10 & No & No \\
\hline 13 & 700 & 3 & $C$ & No & 12 & No & No \\
\hline 14 & 1460 & 2 & $C$ & No & 11 & No & No \\
\hline 15 & 3000 & 1 & $C$ & No & 10 & No & No \\
\hline 16 & 2790 & 1 & $C$ & No & 14 & Yes & Yes** \\
\hline
\end{tabular}

the follow-up after discharge, anastomotic stenosis was evaluated with esophagogram.

A statistically strong correlation was found between Spitz risk classification and anastomotic stenosis (p:0.009). A moderate correlation was found between Spitz risk classification and anastomotic leakage ( $p: 0.036)$. There was no statistically significant relationship between anastomotic leak and anastomotic stenosis $(p>0.05)$.

In the postoperative follow-up, no anastomotic leak or anastomotic stenosis was presented in 5 patients who underwent tense end-to-end anastomosis with vascularized pleural flap. However, no statistically significant relationship was found between anastomosis with and without vascularized pleural flap in terms of anastomotic leakage and stenosis $(p>0.05)$.

\section{Discussion}

In patients with EA, the proximal esophageal pouch may rarely have a high end. The distance between the proximal and distal esophageal pouches may not allow for a nontense end-to-end esophageoesophagostomy. There are different opinions about this situation. Due to the lack of a clear definition for LGEA, the distance that a primary anastomosis can be performed by a surgeon may not be considered as appropriate for primary anastomosis by another surgeon. This situation is also related to the experience of the surgeon. Some surgeons have also defined it as "very long gap" and "ultra long gap". There are also disagreements about whether the distance between proximal and distal esophageal pouches should be measured preoperatively or during surgery. There are even some authors suggesting that distance measurement should be performed before esophageal pouches are released, and there are also authors who state that it should be measured after release $(3,4)$. In our study, considering the article reported by Shieh et al, cases where the distance between the proximal and distal esophageal pouches was more than $3 \mathrm{~cm}$ were accepted as LGEA (2).

Methods such as tense anastomosis, circular myotomy (Livatidis's method), spiral myotomy (Kimura's method), upper pouch flap rotation (Gough's method), suture fistula, gastric pull-up are used in cases with LGEA during surgery (5). Primary end-to-end anastomosis is not a bad option, knowing that it will be a tense anastomosis. As long as the sutures do not rupture the esophagus, it can be accepted 
that the anastomosis procedure will be successful. However, after such tense anastomoses, there is the possibility of anastomotic leakage, anastomotic stricture and even complete separation of the two parts of the esophagus.

Anastomotic leaks have been reported with a rate of $15 \%$ in large series (6). Anastomotic leaks can range from minor leaks detected radiologically to complete separation of the anastomosis. Anastomotic stricture is the most common complication, and its frequency has been reported up to $37 \%$ in some series (7). Among the main causes of anastomotic stenosis, there are: traumatic techniques applied to the esophagus ends during surgery, ischemia, anastomotic leakage etc. In our study, 3 of 16 patients (18\%) who underwent tense end-to-end anastomosis had minor anastomotic leakage detected in the esophagogram taken between $5^{\text {th }} 7^{\text {th }}$ days postoperatively. These anastomotic leaks resolved spontaneously without the need for surgical intervention. Anastomotic stenosis was detected in 4 patients (25\%). It was observed that anastomotic stenosis developed in all 3 patients with a previous minor anastomotic leak. Three of the patients who developed anastomotic stenosis were treated with rigid esophageal dilators with dilatation. Resection and reanastomosis were required for anastomotic stenosis in 1 patient. No anastomotic leakage or anastomotic stenosis was detected in 5 patients who underwent a tense end-toend anastomosis and a vascularized pleural flap was placed over the anastomosis line. This situation is remarkable. However, no statistically significant relationship was found between anastomosis with and without vascularized pleural flap in terms of anastomotic leakage and stenosis. The fact that placing a pleural flap on the anastomosis line with positive results in clinical practice does not produce a statistically significant result is related to the low number of patients. In the literature review we conducted, we realized that the use of vascularized pleural flap, which was previously defined for different surgical interventions, was not defined in the surgical repair of LGEA on the tense end-to- end esophagoesophagostomy line in the first operation. It has been reported that vascularized pleural flap is mostly used in cases with recurrent tracheoesophageal fistula (8). The success of this technique we used in 5 patients without any complications suggested that this technique can be used as a method in tense anastomoses.

A statistically significant relationship was found between the classification of 16 patients who underwent tense end-to-end anastomosis according to Spitz's risk classification and anastomotic leakage. It is noteworthy that all cases with anastomotic leak are cases with Spitz's risk classification 1 . It has been reported that the two most important criteria in the survival of patients with esophageal atresia are birth weight and major cardiac anomaly. It is emphasized that major cardiac anomaly is the most important cause of mortality (9). Although there was no early mortality in the patients, the fact that the cases with complications were Spitz risk classification 1 could not be explained due to the limited number of patients. However, it may be thought that the complications that develop in the postoperative follow-up of the patients have no effect on the survey of the patients.

The average postoperative oral feeding time of patients with EA was reported to be 8 days (10). The postoperative feeding of the patients in our study was usually started with a transanastomotic catheter between $3^{\text {th }} 5^{\text {th }}$ days postoperatively. The time to remove the transanastomotic catheter and start oral feeding was delayed according to the surgeons' recommendations. This oral feeding time is late compared to the literature. However, the time of starting oral feeding in patients with anastomosis with vascularized pleural flap is statistically significantly earlier than the time of starting oral feeding in patients with anastomosis without vascularized pleural flap. This suggests that both the absence of anastomotic leakage in patients using vascularized pleural flap and the surgeon's thought that the presence of vascularized pleural flap preserves the anastomosis line. 
The effect of the use of the pleural flap on the duration of hospitalization could not be objectively evaluated, as the length of hospital stay of patients operated on for EA depends on the additional pathologies and prematurity of the patients. However, it was thought that the use of vascularized pleural flap relatively shortened the duration of hospital stay due to the early oral feeding of the patients and the absence of anastomotic leak and stenosis.

\section{Conclusion}

In conclusion, placing a vascularized pleural flap on the tense end-to-end esophagoesophagostomy line in patients with LGEA in the first operation prevents anastomotic leak and anastomotic stricture in the postoperative period, and allows patients to start early oral feeding. However, this method should be evaluated with larger case series.

\section{Conflict of Interest}

The authors have no conflict of interest to declare.

\section{Financial Disclosure}

The authors declared that this study has received no financial support.

\section{Ethics Committee Approval}

The study was conducted after obtaining approval from the Health Sciences University
Van Education and Research Hospital Clinical Research Ethics Committee.

\section{Author Contributions}

Concept - M.S., M.M.; Design - M.M.; Supervision - M.S., M.M.; Resources - M.S., M.M.; Data Collection and/or Processing - M.S., M.M.; Analysis and/or Interpretation - M.M.; Literature Search - M.M.; Writing Manuscript M.M.; Critical Review - M.S., M.M.

\section{References}

1. Besendörfer M, Müller H, Weiss C, Wagner A, Schellerer V, Hoerning A, et al. Association of clinical factors with postoperative complications of esophageal atresia. Pediatr Neonatol. Epub 2020 Sep 7.

2. Shieh HF, Jennings RW. Long-gap esophageal atresia. Semin Pediatr Surg. 2017;26(2):72-77.

3. Gross ER, Reichstein A, Gander JW, Stolar CJH, Coran AG, Cowles $\mathrm{RA}$. The role of fiberoptic endoscopy in the evaluation and management of long gap isolated esophageal atresia. Pediatr Surg Int. 2010;26(12):1223-7.

4. Chan KL, Saing H. Combined flexible endoscopy and fluoroscopy in the assessment of the gap between the two esophageal pouches in esophageal atresia without fistula. J Pediatr Surg. 1995;30(5):668-70.

5. Laberge JM and Guttman: Esophageal atresia and related tracheoesophageal anomalies. In Donnellan WL et al. (eds.): Abdominal Surgery of Infancy and Childhood. Luxembourg: Harwood Academic Publishers; 1996, p.11/1-34.

6. Chittmittrapap S, Spitz L, Kiely EM, Brereton RJ. Anastomotic leakage following surgery for esophageal atresia. J Pediatr Surg. 1992; 27(1):29-32.

7. Chittmittrapap S, Spitz L, Kiely EM, Brereton RJ. Anastomotic stricture following surgery for esophageal atresia. J Pediatr Surg. 1990;25(5):508-11.

8. Briganti V, Mangia G, lalongo P, Calisti A. Usefulness of large pleural flap for the treatment of children with recurrent tracheoesophageal fistula. Pediatr Surg Int. 2009 Jul;25(7):587-9.

9. Malakounides G, Lyon P, Cross K, Pierro A, De Coppi P, Drake D, et al.: Esophageal atresia. Improved outcomes in high-risk groups revisited. Eur J Pediatr Surg. 2016;26(3):227-31. Epub 2015 Jun 16.

10. Lees MC, Bratu I, Yaskina M, van Manen M. Oral feeding outcomes in infants with esophageal atresia and tracheoesophageal fistula. J Pediatr Surg. 2018;53(5):929-932. 